\title{
REMOVAL OF CATARACT WITH THE CAPSULE
}

BY

\author{
DR. ANDREW LICSKó \\ BUDAPEST
}

Ophthalmologists still differ on the subject of the removal of senile cataract in the capsule, though the ambition of operators to achieve this ideal result with regard to vision is of considerable antiquity. S. Sharp in 1753 and Daviel ${ }^{(\mathbf{1})}$ in 1782 both performed intracapsular extractions ; and since Pagenstecher's ${ }^{(2)}$ work in 1874 the operation has taken its place as a recognized procedure.

The operations for the intracapsular extraction of cataract may, as regards operative technique, be divided into three classes: in

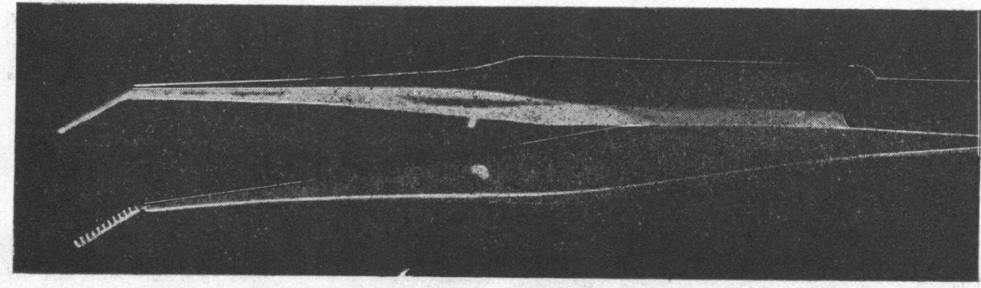

Fig. 1.

the first method the zonula is torn by pressure on the cornea from without; in the second by means of instruments constructed specially for the purpose; and in the third the removal of the lens is executed by suction apparatus.

The operation as carried out at the No. 1 Qphthalmological Hospital of Budapest (Director, Professor Emile de Grósz) differs but slightly both as to technique and instruments used from the ordinary extracapsular extraction as performed in this hospital for several decades. I have sometimes experienced in performing the ordinary extraction that the capsule of the lens was not torn by the capsule forceps employed, but luxated, and the lens and capsule were removed together. Observing this circumstance I noted that it was not due to the thickness of the lens capsule but to the fact that the teeth of the forceps (Schulek's, Fig. 1) which were usually employed had become worn. I then had a Schulek forceps made with the teeth carefully ground down (Fig. 2) and used this for the purpose. It is essential that the forceps should not be sharp for then it will inevitably cut through the lens capsule.

The operation with this forceps is performed as follows : for twenty minutes prior to the operation one drop of 5 per cent. 
cocain-tonogen solution is dropped into the eye three times every five minutes, and just before the operation one drop of 1 per cent. atropin. Snowden's speculum is used in order to keep the eyelids widely apart, and in most cases the superior rectus is fixed as described by Blaskovich ${ }^{(3)}$. The thread is stitched through the rectus without freeing the conjunctiva. An incision somewhat larger than one-third of the cornea (except in cases of Morgagnian cataract) is then made with a Graefe knife. A large

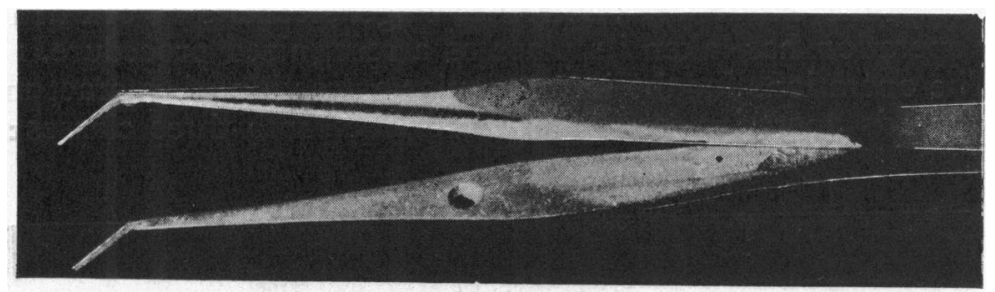

FIG. 2.

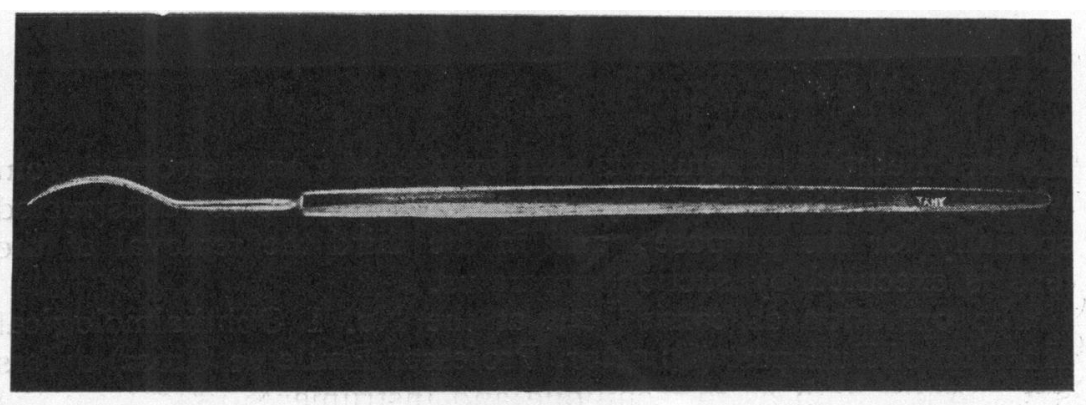

FIG. 3.

conjunctival flap is cut and folded back. I consider it essential to perform an iridectomy as the complete lens in its capsule forces the edges of the iris into the wound. The toothless forceps is then employed to take a broad hold of the capsule at the equator, or preferably a little above it, and gently closed. It is advisable to take hold of the capsule rather above the equator as if it is seized at a lower level the lower part of the zonula may give way first and the lens appear in the wound with its transverse diameter, an event which, though not in itself dangerous, may, if the section is not large enough, lead to rupture of the lens capsule. The operator makes lateral movements with the closed forceps 
so as to rupture the zonula and draw the lens into the wound. At the same time pressure is exerted from below upwards along the lower border of the lens by means of the annular expressor, an instrument also devised by Schulek (Fig. 3).

If the lens is not in very close connection with the capsule the latter readily gives way after a few lateral motions, following which the lens is immediately luxated into the anterior chamber and easily removed. It is sometimes advisable, apart from the lateral movements, to push the lens upwards. If, however, the lens is in close connection with the zonula, which can be perceived immediately on attempting the extraction, it is preferable to exercise a steadily increasing pressure sideways and upwards, instead of the lateral jerks, assisted of course by the annular expressor, since it may happen that the lens capsule is less resistant than the zonula and gives way first. Not the least important part of this operation is the pressure brought to bear on the lower edge of the lens. This pressure must be constant, steady, and not too hard. The hand holding the instrument must always feel the elasticity of the vitreous which rolls out the lens under the united influence of the aforesaid factors, the traction of the forceps and the pressure exerted by the instrument. Should the pressure exceed the elasticity of the vitreous the hyaloid membrane will rupture and the lens fall back into the vitreous displacing this structure into the wound. After the lens has been removed the edges of the wound must be carefully cleaned and replaced. This concludes the operation. Both eyes are bandaged for one day and the eye that has been operated on for five days.

In the two and a half years dating from January, 1923, I have dealt with 204 senile cataracts in the way described at the No. 1 Ophthalmological Hospital, Budapest. Sixty-one, i.e., 30) per cent. were successful. This percentage has improved during the last six months to 50 per cent. as the technique became more perfect. Experiences with regard to operative technique, recovery, and final results have convinced me of the value of the operation.

The low percentage of successful intracapsular extraction may be taken to show that the operations were carried out with the utmost care, and that the lens capsule was ruptured in preference to running any risk of vitreous loss. To this caution it is due that in the whole series there was only one case of vitreous loss during the operation. This occurred on making the section in a case of complicated cataract. In two other cases, one of normal and the other of complicated cataract the patient pressed the speculum on the eye at the end of the operation and caused vitreous loss. In the normal case vitreous loss was followed by irido-choroiditis, the only case of post-operative infection that 
occurred. Recovery was prolonged in one case by a protracted mild iritis; the final visual result was 5/7. In one other case irido-dialysis with considerable haemorrhage resulted from the iris being adherent to the lens capsule; the final visual result in this case was $5 / 10$.

\begin{tabular}{|c|c|c|c|c|c|c|c|}
\hline \multirow[b]{2}{*}{ Number of Cases. } & \multicolumn{2}{|c|}{ Complications. } & \multirow[b]{2}{*}{$\begin{array}{l}\text { Wound } \\
\text { reopening. }\end{array}$} & \multirow[b]{2}{*}{ Infection. } & \multicolumn{3}{|c|}{ Final results. } \\
\hline & $\begin{array}{c}\text { Prolapse } \\
\text { of } \\
\text { vitreous. }\end{array}$ & $\begin{array}{c}\text { Irido- } \\
\text { dialysis. }\end{array}$ & & & $\begin{array}{l}5 / 5 \\
5 / 10\end{array}$ & $\begin{array}{l}\text { Vision. } \\
5 / 15 \\
5 / 30\end{array}$ & $\begin{array}{l}5 / 30 \\
5 / 70\end{array}$ \\
\hline $\begin{array}{l}\text { Non-complicated } \\
\text { cataract : } 57 .\end{array}$ & $1^{*}$ & 1 & 12 & $\begin{array}{c}\text { Iritis } 1 . \\
\text { Irido- } \\
\text { cyclitis : } 1 .\end{array}$ & 48 & 6 & 3 \\
\hline $\begin{array}{l}\text { High Myopia and } \\
\text { cataract: } 2 \text {. }\end{array}$ & - & - & - & - & $\begin{array}{l}\text { In on } \\
\text { atrop } \\
5 / 30 \text {. } \\
\text { In } \\
\text { vitreo } \\
\text { tingui } \\
3 \text { yarc }\end{array}$ & $\begin{array}{l}\text { case p } \\
\text { ay of c } \\
\text { another } \\
\text { us haz } \\
\text { shes fin } \\
\text { is. }\end{array}$ & $\begin{array}{l}\text { eripap. } \\
\text { horoid, } \\
\text { case } \\
\text {; dis- } \\
\text { gers at }\end{array}$ \\
\hline $\begin{array}{l}\text { Complicated } \\
\text { cataract : } 2 .\end{array}$ & $1+1^{*}$ & - & 1 & - & $\begin{array}{l}\text { In or } \\
\text { retina } \\
\text { case, } \\
\bar{c}+10 \\
\text { guish } \\
1 \text { yard }\end{array}$ & $\begin{array}{l}\text { le case, } \\
\text { e. In } \\
\text { blatio } \\
\text { D. sph. } \\
\text { es fing } \\
\text {. }\end{array}$ & $\begin{array}{l}\text { ablatio } \\
\text { nother } \\
\text { etinae; } \\
\text { distin- } \\
\text { ers at }\end{array}$ \\
\hline
\end{tabular}

* Patient, after operation, pressed the speculum on his eye.

In twelve cases the recovery was complicated by the wound giving way, and in one of these paracentesis of the cornea was required. This complication is also met with in extracapsular extraction, and the intracapsular operation cannot be blamed for it. In these cases the final visual results were $5 / 15$ to $5 / 10$ in nine and $5 / 30$ in the remainder. This is a better result than could be expected in the ordinary extracapsular extraction, since in that case the tendency to the formation of a dense secondary cataract from the extravasated blood and lens fragments would be great.

The great gain from the intracapsular operation is the clear vision obtained, at least $5 / 7$ in cases with clear media and a healthy fundus. In one case post-operative astigmatism reached $5 \mathrm{D}$., but as a rule was neither greater nor less than that found after the usual operation. 
Amongst the sixty-one cases there were 28 immature, 19 mature, 8 hypermature, 4 complicated, and 1 myopic. I consider that a great advantage of the operation consists in the elimination of secondary cataract especially in operations on immature cases. The procedures necessary for the removal of cortex must cause a certain amount of bruising of the tissues and may possibly lead to vitreous loss. Further, there is the necessity of dealing with the secondary cataract, a procedure not free from risk of infection and secondary glaucoma, and which may not yield an opening of a satisfactory type. A further advantage of the operation here described is to be found in the gentle nature of the procedure which exposes the patient to the minimum of risk.

\section{LITERATURE}

1. Daviel._- "Sur une nouvelle méthode de guérir la cataracte par l'extraction." Mem. de l'Acad. Roy. de Chir., 1782.

2. Pagenstecher.- "Ueber Staroperationen mit und ohne Entfernung der Kapsel." Arch.f. Ophthal., Vol. XXXIV.

Knapp.- " Report of a series of extractions of cataract in the capsule after subluxation with capsule forceps." Trans. Amer. Ophthal. Soc., 1914.

3. v. Blaskovich.-" Eine neuartige Fixierung des Augapfels." Ungar. Ophthal. Gessells., 1912.

\section{ANNOTATION}

\section{Nero's Emerald}

Our readers are familiar with the story of the use made by Nero of an emerald to assist his weak sight when attending the games in the circus. The general belief was that this particular emerald was concave and that Nero was myopic. Dr. Marc Landolt has contributed a scholarly article on the subject in a recent number of the Archives d'Ophtalmologie (Feb., 1926). It appears that the legend is derived from a passage in Pliny and that the meaning thereof depends on the situation of a comma. As Latin writers in Pliny's time did not use commas the necessary comma may be inserted according to the pleasure of the translator. The actual passage reads as follows : "nisi cum conniveret ad prope admota hebetes." One side inserts the comma after the word admota, while the other side elects to place it after conniveret. In the first arrangement the meaning would indicate that Nero could only see near objects and was myopic. The second reading would indicate that Nero's vision for near objects was defective. In this latter 